\title{
Comparative susceptibility of turbot Scophthalmus maximus to different genotypes of viral haemorrhagic septicaemia virus
}

\author{
M. Snow*, J. A. King, A. Garden, A. M. Shanks, R. S. Raynard \\ Fisheries Research Services (FRS) Marine Laboratory, PO Box 101, 375 Victoria Road, Aberdeen AB11 9DB, UK
}

\begin{abstract}
Viral haemorrhagic septicaemia (VHS) disease has exerted a significant impact on the development of turbot aquaculture in the British Isles. The source of such outbreaks is believed to be naturally occurring marine isolates of viral haemorrhagic septicaemia virus (VHSV), which are endemic in the marine environment of Northern Europe. Genetic studies have classified these marine VHSV isolates into genotypes based on their geographic rather than host-species origin. This study set out to explore the hypothesis that susceptibility of turbot to VHSV might be genotype specific. Immersion infection of turbot with a range of isolates, selected according to genotype, identified significant differences between susceptibility and genotype. Viruses belonging to Genotypes Ib (Baltic marine isolates) and III (North Sea/E. Atlantic marine isolates) caused significantly higher mortality than isolates from Genotypes Ia (isolates associated with rainbow trout aquaculture) and II (Baltic marine isolates). This study serves to highlight the importance of thoroughly investigating the susceptibility of any given species to the range of pathogens to which they might be exposed prior to considering them resistant to any disease. Furthermore, it highlights different risk factors that might be associated with turbot aquaculture undertaken in different environments. Finally, an increased knowledge of the relative virulence of different isolates in turbot will assist in understanding virulence determinants, which could lead to advances in disease control.
\end{abstract}

KEY WORDS: Scophthalmus maximus $\cdot$ Viral haemorrhagic septicaemia $\cdot$ Genotype $\cdot$ Susceptibility

Resale or republication not permitted without written consent of the publisher

\section{INTRODUCTION}

Viral haemorrhagic septicaemia virus (VHSV) is a rhabdovirus which is responsible for the most significant viral disease of cultured rainbow trout Oncorhynchus mykiss in continental Europe. Outbreaks of disease in European turbot Scophthalmus maximus aquaculture in the early 1990s (Schlotfeldt et al. 1991, Ross et al. 1994, J. McArdle unpubl.) led to the realisation that viral haemorrhagic septicaemia (VHS) was not, however, an exclusively freshwater disease. Although VHSV was first recovered from the marine environment as early as 1979 (Jensen et al. 1979), a widespread marine distribution of the agent has only been recognised since the late 1980s, with the isolation of virus from an increasing range of wild-caught marine host species in North America (Brunson et al. 1989, Hopper 1989, Meyers et al. 1992, Meyers et al. 1994, Traxler \& Kieser 1994, Meyers \& Winton 1995, Meyers et al. 1999, Traxler et al. 1999), Japan (Takano et al. 2000) and Europe (Smail 1995, 2000, Dixon et al. 1997, Mortensen et al. 1999, King et al. 2001b, Brudeseth \& Evensen 2002). Indeed, over 150 isolations from a wide range of wild-caught marine host species have now been made in Europe alone.

Studies investigating the molecular evolution of VHSV have identified 4 major genetic groups of viruses (genotypes) (Snow et al. 1999, 2000, EinerJensen et al. 2004). Genotype I includes viruses isolated from disease epizootics in rainbow trout farms 
(Genotype Ia) along with a group of naturally occurring isolates originating from wild marine fish species residing predominantly within the Baltic Sea (Genotype Ib) (Benmansour et al. 1997, Stone et al. 1997, Snow et al. 1999, 2004, Nishizawa et al. 2002, Thiery et al. 2002, Einer-Jensen et al. 2004). Evidence suggests that an ancestor of marine Genotype Ib was the original source of introduction of VHSV into the rainbow trout industry (for review see Snow et al. 2004). Since all marine isolates tested to date appear to be of low virulence to rainbow trout (Dixon et al. 1997, Skall et al. 2004), the evolution of a virulent phenotype appears to have occurred within rainbow trout aquaculture, where genetic evolution of the virus is known to be accelerated (Einer-Jensen et al. 2004). An additional genotype (Genotype II) has also been shown to be present in marine fish species in the Baltic Sea (Snow et al. 1999, 2004, EinerJensen et al. 2004). This genotype appears less prevalent than Genotype Ib (Mortensen et al. 1999, Snow et al. 2004), and to date has not been associated with losses in rainbow trout aquaculture. The final genetic group represented in Europe is Genotype III, which is distributed in wild marine fish species in the Eastern Atlantic, North Sea and Kattegat/Skagerrak (Benmansour et al. 1997, Stone et al. 1997, Snow et al. 1999, 2004, Einer-Jensen et al. 2004). Genotype IV is composed of all North American isolates which to date have all been recovered from marine or anadromous fish species (Benmansour et al. 1997, Stone et al. 1997, Mortensen et al. 1999, Snow et al. 1999, 2004, Nishizawa et al. 2002, Einer-Jensen et al. 2004).

The susceptibility of turbot Scophthalmus maximus to VHSV was first demonstrated in 1984, using a freshwater rainbow trout strain of virus (Castric \& de Kinkelin 1984). A subsequent outbreak of VHSV in farmed turbot in Germany (Schlotfeldt et al. 1991) confirmed the natural susceptibility of this species. The causative virus in this instance was later shown to belong to Genotype Ia, and was most likely introduced as a direct result of rainbow trout farming activities (Schlotfeldt et al. 1991, Snow et al. 2004). Further VHS disease outbreaks in turbot farms in the British Isles have been shown to be caused by Genotype III viruses, which highlights a direct risk to the commercial culture of this species from an endemic reservoir of marine virus (Ross et al. 1994, Stone et al. 1997, Snow et al. 1999, 2004). The susceptibility of turbot following water-borne infection to 2 Genotype III viruses (UK-860/94 and DK-4p168) has also been experimentally demonstrated (Snow \& Smail 1999, King et al. 2001a). In these studies, average cumulative mortalities of $71.1 \%$ (Snow \& Smail 1999) and $66.3 \%$ were obtained for Isolates UK-860/94 and DK4p168, respectively (Table 1) (King et al. 2001a). Susceptibility testing using additional isolates suggested that different genotypes of VHSV cause different levels of mortality in turbot as they do to trout (Table 1) (King et al. 2001a).

Since previous virulence studies have only included limited numbers of isolates from Genotypes II and III, this study was initiated to further investigate the relationship between virus genotype and virulence in turbot. The potential for anthropogenic movements associated with aquaculture to expose cultured species to virus of differing geographic origin render this an important issue to address. In addition to highlighting relative risks to turbot farms located in different geographic regions, the identification of viruses exhibiting different pathogenicity in turbot will facilitate further research aimed at identifying potentially species-specific pathogenicity determinants in this important fish rhabdovirus.

Table 1. Summary of the results of previous challenges testing the susceptibility of juvenile turbot Scophthalmus maximus to strains of marine viral haemorrhagic septicaemia virus (VHSV)

\begin{tabular}{|c|c|c|c|c|c|}
\hline Origin & Genotype & Isolate name & $\begin{array}{l}\text { Mortality reported } \\
\% \pm \mathrm{SE}\end{array}$ & Source & $\begin{array}{l}\text { Mortalitiy obtained } \\
\text { in this study }(\%)\end{array}$ \\
\hline $\begin{array}{l}\text { Freshwater European } \\
\text { rainbow trout }\end{array}$ & Ia & DK-3592B & $2.9 \pm 1.7$ & King et al. (2001a) & Not tested \\
\hline Baltic Sea sprat & $\mathrm{Ib}$ & DK-1p121 & $13.5 \pm 2.6$ & King et al. (2001a) & 18.0 \\
\hline Baltic Sea herring & $\mathrm{Ib}$ & DK-1p3 & $16.5 \pm 6.9$ & King et al. (2001a) & 28.1 \\
\hline Baltic Sea herring & $\mathrm{Ib}$ & DK-1p12 & $37.4 \pm 0.2$ & King et al. (2001a) & 44.9 \\
\hline Baltic Sea herring & $\mathrm{Ib}$ & DK-1p110 & $27.9 \pm 2.6$ & King et al. (2001a) & Not tested \\
\hline Baltic Sea herring & $\mathrm{Ib}$ & DK-1p125 & $39.0 \pm 6.2$ & King et al. (2001a) & 24.4 \\
\hline Baltic Sea sprat & $\mathrm{Ib}$ & DK-1p86 & $0.9 \pm 0.9$ & King et al. (2001a) & Not tested \\
\hline Baltic Sea sprat & II & DK-1p52 & 0 & King et al. (2001a) & 1.1 \\
\hline Baltic Sea sprat & II & DK-1p55 & $0.9 \pm 0.9$ & King et al. (2001a) & 5.4 \\
\hline Turbot Gigha, & III & UK-860/94 & 71.1 & Snow \& Smail (1999) & 46.7 \\
\hline West Scotland & & & $66.3 \pm 1.8$ & King et al. (2001a) & 46.7 \\
\hline Skaggerak herring & III & DK-4p168 & 66.3 & King et al. (2001a) & 48.4 \\
\hline
\end{tabular}




\section{MATERIALS AND METHODS}

Fish. Turbot Scophthalmus maximus (mean weight $\pm \mathrm{SE}, 4.6 \pm 0.9 \mathrm{~g}$ ) were obtained from Mannin Seafarms, Isle of Man. Fish were tested for the presence of infectious pancreatic necrosis virus (IPNV), infectious haematopoietic necrosis virus (IHNV) and VHSV prior to the experiment. Organs collected from a total of 30 fish (pooled into 6 samples of 5 fish each) were virologically examined using previously described methods (Snow \& Smail 1999). Fish were acclimated for at least $14 \mathrm{~d}$ after arrival at the laboratory and were fed a commercial diet and maintained on a photoperiod of $12 \mathrm{~h}$ day: $12 \mathrm{~h}$ night at $10 \pm 1^{\circ} \mathrm{C}$ in aerated sea water (sand filtered from Nigg Bay, Aberdeen) throughout the trial.

Cell culture and virus propagation. Viruses selected from the different genotypes and used for all challenge experiments are detailed in Table 2 . Stocks of virus were grown on the bluegill fry caudal trunk cell line (BF-2) (Wolf \& Quimby 1966) in Eagles minimum essential medium (Gibco BRL, Life Technologies) supplemented with $5 \%$ foetal bovine serum (EMEM-5). Challenge virus stocks were prepared following a maximum of 6 passages in cell culture in each case. Each virus was diluted in EMEM-5 to give a final dose of $10^{9} \mathrm{TCID}_{50} \mathrm{ml}^{-1}$, which was added to $10 \mathrm{l}$ water to provide a challenge dose of $10^{5} \mathrm{TCID}_{50} \mathrm{ml}^{-1}$.

Experimental infection. Triplicate groups of turbot ( $\mathrm{n}=23$ to 33 ; Table 2 ) were transferred into clean polythene bags containing $10 \mathrm{l}$ seawater which were then each placed in a clean 301 tank. Aliquots of each virus, prepared as above, were poured into each of the triplicate bags for each isolate. Triplicate controls were also set up where EMEM-5 containing no virus was added to each bag. Polythene bags were tied to contain aerosols and reduce the risk of cross-contamination between tanks. Each tank received aeration for the duration of the challenge $(5 \mathrm{~h})$, after which time the fish were carefully released and normal flow rates (50 1 $\mathrm{h}^{-1}$ ) established to raise the volume in each tank to its normal level (30 l).

Sampling regime. Fish were checked twice daily and mortalities were removed, stored whole at $-80^{\circ} \mathrm{C}$ and individually sampled at a later date for virological examination as previously described (King et al. 2001a). The experiment was terminated on Day 69 when surviving fish were euthanased and organs sampled from pools of 5 fish for virological examination (kidney, spleen). All cell cultures showing evidence of CPE were tested by ELISA using a commercial diagnostic kit according to the manufacturer's instructions (Test-Line Limited Clinical Diagnostics) to confirm the presence of VHSV.

\section{RESULTS}

\section{Infection of turbot with VHSV}

A summary of the mortality data obtained following immersion infection of turbot with different isolates of VHSV is detailed in Table 2. All mortalities were virologically evaluated for the presence of VHSV which was confirmed by subsequent ELISA. Of 455 mortalities overall, 432 were attributable to VHSV and thus only these were considered for analytical purposes. Non-specific mortalities accounted for 0.013 of all experimental fish. These deaths were not distributed uniformly over the 18 isolates and control group, as measured by a chi-squared goodness of fit test $\left(\chi^{2}=\right.$ $52.175, \mathrm{df}=18)$. The largest number of unexplained deaths (7) occurred with isolate DK-1p125, and 5 unexplained deaths occurred with isolate DK-1p55 (Table 2).

The results from replicate tanks are fairly consistent, with the exceptions of the tanks infected with virus isolates DK-1p121, DK-1p12, DK-1p54 and DK1p55. In the case of Isolate DK-1p121, one replicate tank had 11 deaths due to VHSV, while there were 4 and 1 such deaths in the other 2 replicate tanks. For Isolate DK-1p12 there were 8, 19 and 13 mortalities in replicate tanks. For both DK-1p54 and DK-1p55, 1 replicate tank had 5 mortalities while the other 2 replicates had none. In these cases, overdispersion was indicated; that is to say, the variance in the 3 numbers of deaths, from the 3 replicate tanks treated with the same isolate, was larger than their mean, when these 2 estimates would have been expected to be approximately equal.

Overall mortalities attributable to VHSV for each isolate ranged from 0 (control group and DK-1p49) to 0.787 (IR-F13.02.97) and are ranked in Table 3. A generalized linear mixed model was fitted in GENSTAT, where genotype was taken to be a fixed effect and isolate was taken to be random. The binomial distribution was assumed and the link function was the logit. The overdispersion referred to above was taken account of in the model fitting. The effect of genotype was found to be significant, with Genotype III having a higher probability of death than Genotype Ia, Ib and II. However, the difference between Genotypes III and Ib is of borderline significance. It is seen in Table 3, that within Genotype III there is one isolate for which the death rate $(0.787)$ is higher than the others in that genotype (range from 0.440 to 0.484 ).

Isolate DK-1p12 of Genotype Ib gave a proportion of 0.449, which ranked amongst those for Genotype III, otherwise the proportions for Genotype Ib formed a distinct group. Genotypes Ia and II, although distinct from Genotypes Ib and III, did not themselves form 2 
Table 2. List of 18 viral haemorrhagic septicaemia virus (VHSV) isolates selected for immersion challenge of turbot Scophthalmus maximus in this study. Total fish numbers challenged with each isolate in individual tank replicates $(\mathrm{n}=3$ in each case) are indicated, along with the number and proportion of VHSV-associated mortalities obtained within the experimental period (69 d)

\begin{tabular}{|c|c|c|c|c|c|c|c|}
\hline \multirow[t]{2}{*}{ Origin } & \multirow[t]{2}{*}{ Species } & \multirow[t]{2}{*}{ Genotype } & \multirow[t]{2}{*}{ Isolate name } & \multirow{2}{*}{$\begin{array}{c}\text { Total fish } \\
\text { number } \\
\text { (replicate tanks) }\end{array}$} & \multicolumn{2}{|c|}{$\begin{array}{l}\text { VHSV associated } \\
\text { mortalities }\end{array}$} & \multirow{2}{*}{$\begin{array}{c}\text { Non-VHSV associated } \\
\text { mortalities } \\
\text { No. }\end{array}$} \\
\hline & & & & & No. & Proportion & \\
\hline & & & Control & 31 & 0 & 0 & 0 \\
\hline & & & & 29 & 0 & 0 & 0 \\
\hline & & & & 29 & 0 & 0 & 0 \\
\hline \multirow{3}{*}{$\begin{array}{l}\text { North American } \\
\text { cod }\end{array}$} & \multirow[t]{3}{*}{ Gadus macrocephalus } & \multirow[t]{3}{*}{ IV } & \multirow[t]{3}{*}{ US-pws-ak90 } & 29 & 1 & 0.034 & 1 \\
\hline & & & & 31 & 1 & 0.032 & 0 \\
\hline & & & & 30 & 1 & 0.033 & 0 \\
\hline Freshwater & \multirow[t]{3}{*}{ Oncorhynchus mykiss } & \multirow[t]{3}{*}{ Ia } & \multirow[t]{3}{*}{ DK-3592B } & 30 & 1 & 0.033 & 0 \\
\hline European & & & & 30 & 0 & 0 & 0 \\
\hline rainbow trout & & & & 30 & 1 & 0.033 & 0 \\
\hline Freshwater & \multirow{3}{*}{ Oncorhynchus mykiss } & \multirow[t]{3}{*}{ Ia } & FR-07.71 & 30 & 0 & 0 & 0 \\
\hline European & & & & 30 & 0 & 0 & 0 \\
\hline rainbow trout & & & & 30 & 1 & 0.033 & 0 \\
\hline Baltic Sea cod & Gadus morhua & $\mathrm{Ib}$ & DK-1e62 & 30 & 11 & 0.367 & 0 \\
\hline & & & & 30 & 10 & 0.333 & 1 \\
\hline & & & & 30 & 9 & 0.3 & 0 \\
\hline Baltic Sea sprat & Sprattus sprattus & $\mathrm{Ib}$ & DK-1p121 & 30 & 4 & 0.133 & 0 \\
\hline & & & & 30 & 11 & 0.367 & 0 \\
\hline & & & & 29 & 1 & 0.034 & 0 \\
\hline Baltic Sea herring & Clupea harengus & $\mathrm{Ib}$ & DK-1p12 & 30 & 8 & 0.267 & 1 \\
\hline & & & & 31 & 19 & 0.613 & 0 \\
\hline & & & & 28 & 13 & 0.464 & 0 \\
\hline Baltic Sea herring & Clupea harengus & $\mathrm{Ib}$ & DK-1p3 & 30 & 6 & 0.2 & 1 \\
\hline & & & & 30 & 12 & 0.4 & 1 \\
\hline & & & & 29 & 7 & 0.241 & 0 \\
\hline Baltic Sea herring & Clupea harengus & $\mathrm{Ib}$ & DK-1p125 & 29 & 7 & 0.241 & 3 \\
\hline & & & & 30 & 8 & 0.267 & 0 \\
\hline & & & & 31 & 7 & 0.226 & 4 \\
\hline Baltic Sea herring & Clupea harengus & II & DK-1p49 & 30 & 0 & 0 & 0 \\
\hline & & & & 30 & 0 & 0 & 0 \\
\hline & & & & 31 & 0 & 0 & 0 \\
\hline Baltic Sea sprat & Sprattus sprattus & II & DK-1p52 & 30 & 0 & 0 & 0 \\
\hline & & & & 30 & 1 & 0.033 & 0 \\
\hline & & & & 30 & 0 & 0 & 0 \\
\hline Baltic Sea sprat & Sprattus sprattus & II & DK-1p54 & 28 & 0 & 0 & 0 \\
\hline & & & & 30 & 0 & 0 & 0 \\
\hline & & & & 30 & 5 & 0.167 & 1 \\
\hline Baltic Sea sprat & Sprattus sprattus & II & DK-1p55 & 30 & 0 & 0 & 1 \\
\hline & & & & 30 & 0 & 0 & 1 \\
\hline & & & & 32 & 5 & 0.156 & 3 \\
\hline North Sea lesser & Argentina sphyraena & III & DK-4p51 & 30 & 11 & 0.367 & 0 \\
\hline Argentine & & & & 29 & 16 & 0.552 & 0 \\
\hline & & & & 29 & 13 & 0.448 & 0 \\
\hline Turbot Gigha, & Scophthalmus maximus & III & UK-860/94 & 33 & 14 & 0.424 & 0 \\
\hline West Scotland & & & & 29 & 16 & 0.552 & 0 \\
\hline & & & & 30 & 13 & 0.433 & 0 \\
\hline Turbot & Scophthalmus maximus & III & IR-F13.02.97 & 31 & 25 & 0.806 & 0 \\
\hline SW Ireland & & & & 32 & 26 & 0.812 & 0 \\
\hline & & & & 31 & 23 & 0.742 & 0 \\
\hline Skaggerak & Clupea harengus & III & DK-4p168 & 32 & 12 & 0.375 & 1 \\
\hline herring & & & & 30 & 16 & 0.533 & 1 \\
\hline & & & & 31 & 17 & 0.548 & 0 \\
\hline North Atlantic & Gadus morhua & III & MLA98/4CO1 & 30 & 15 & 0.5 & 0 \\
\hline Cod & & & & 31 & 13 & 0.419 & 0 \\
\hline & & & & 30 & 15 & 0.5 & 2 \\
\hline North Atlantic & Trisopterus esmarkii & III & MLA98/4PT1 & 23 & 9 & 0.391 & 0 \\
\hline Norway pout & & & & 31 & 17 & 0.548 & 0 \\
\hline & & & & 30 & 11 & 0.367 & 1 \\
\hline
\end{tabular}


Table 3. Total number and proportion of viral haemorrhagic septicaemia virus (VHSV)-associated mortalities obtained following immersion challenge with each of the 18 VHSV isolates

\begin{tabular}{|c|c|c|c|c|c|}
\hline Origin & Genotype & Isolate name & $\begin{array}{c}\text { Total fish } \\
\text { number in challenge }\end{array}$ & $\begin{array}{l}\text { Total number of VHSV } \\
\text { associated mortalities }\end{array}$ & $\begin{array}{c}\text { Proportion of } \\
\text { mortalities }\end{array}$ \\
\hline Turbot SW Ireland & III & IR-F13.02.97 & 94 & 74 & 0.787 \\
\hline Skaggerak Herring & III & DK-4p168 & 93 & 45 & 0.484 \\
\hline North Atlantic cod & III & MLA98/4CO1 & 91 & 43 & 0.473 \\
\hline $\begin{array}{l}\text { Turbot Gigha, } \\
\text { West Scotland }\end{array}$ & III & UK-860/94 & 92 & 43 & 0.467 \\
\hline $\begin{array}{l}\text { North Sea lesser } \\
\text { Argentine }\end{array}$ & III & DK-4p51 & 88 & 40 & 0.455 \\
\hline Baltic Sea Herring & $\mathrm{Ib}$ & DK-1p12 & 89 & 40 & 0.449 \\
\hline $\begin{array}{l}\text { North Atlantic } \\
\text { Norway pout }\end{array}$ & III & MLA98/4PT1 & 84 & 37 & 0.440 \\
\hline Baltic Sea cod & $\mathrm{Ib}$ & DK-1e62 & 90 & 30 & 0.333 \\
\hline Baltic Sea herring & $\mathrm{Ib}$ & DK-1p3 & 89 & 25 & 0.281 \\
\hline Baltic Sea herring & $\mathrm{Ib}$ & DK-1p125 & 90 & 22 & 0.244 \\
\hline Baltic Sea sprat & $\mathrm{Ib}$ & DK-1p121 & 89 & 16 & 0.180 \\
\hline Baltic Sea sprat & II & DK-1p54 & 88 & 5 & 0.057 \\
\hline Baltic Sea sprat & II & DK-1p55 & 92 & 5 & 0.054 \\
\hline North American cod & IV & US-pws-ak90 & 90 & 3 & 0.033 \\
\hline $\begin{array}{l}\text { Freshwater European } \\
\text { rainbow trout }\end{array}$ & Ia & DK-3592B & 90 & 2 & 0.022 \\
\hline Baltic Sea Sprat & II & DK-1p52 & 90 & 1 & 0.011 \\
\hline $\begin{array}{l}\text { Freshwater European } \\
\text { rainbow trout }\end{array}$ & Ia & FR-07.71 & 90 & 1 & 0.011 \\
\hline Baltic Sea herring & II & DK-1p49 & 91 & 0 & 0.000 \\
\hline & & Control & 89 & 0 & 0.000 \\
\hline
\end{tabular}

distinct clusters. The probabilities of mortality for the 4 genotypes along with $95 \%$ confidence limits are shown in Fig. 1.

The day on which the first mortality due to VHSV was found in each tank was considered and Fig. 2 shows proportion of mortalities plotted against day of first death for all tanks in which at least one mortality took place. There is evidence that where mortalities due to the virus were most prevalent the first such death took place early in the monitoring period. The

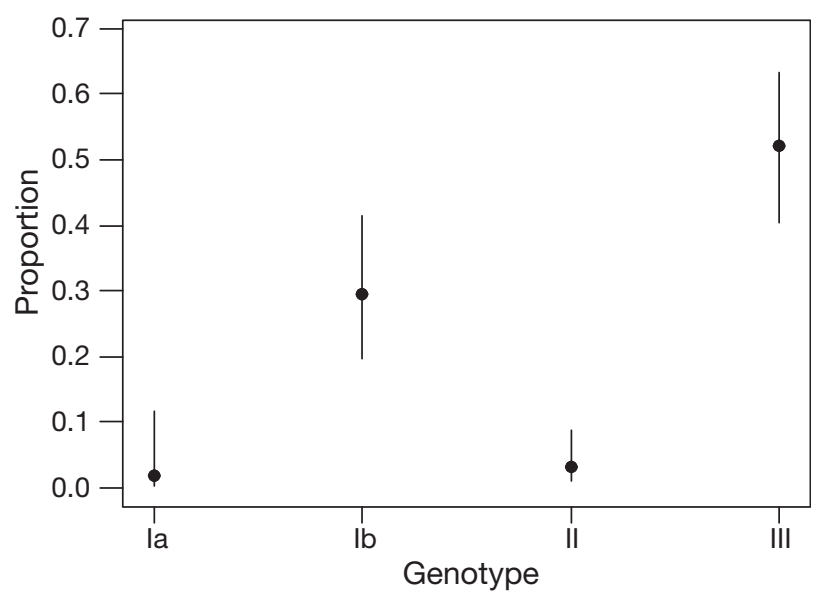

Fig. 1. Scophthalmus maximus. Plot of proportions of mortalities predicted from the model for each genotype, along with approximate $95 \%$ confidence limits earliest VHSV death occurred on Day 13 of monitoring in one tank replicate of Isolate DK-4p168 (data not shown). The first and only death in a tank replicate of Isolate DK-3592B occurred on Day 61 (data not shown). A Spearman's rank correlation coefficient of -0.714 ( $p<0.001$ ) was computed for the 42 tanks in which at least one mortality occurred, indicating a significant negative association between proportion of mortalities and day of first death.

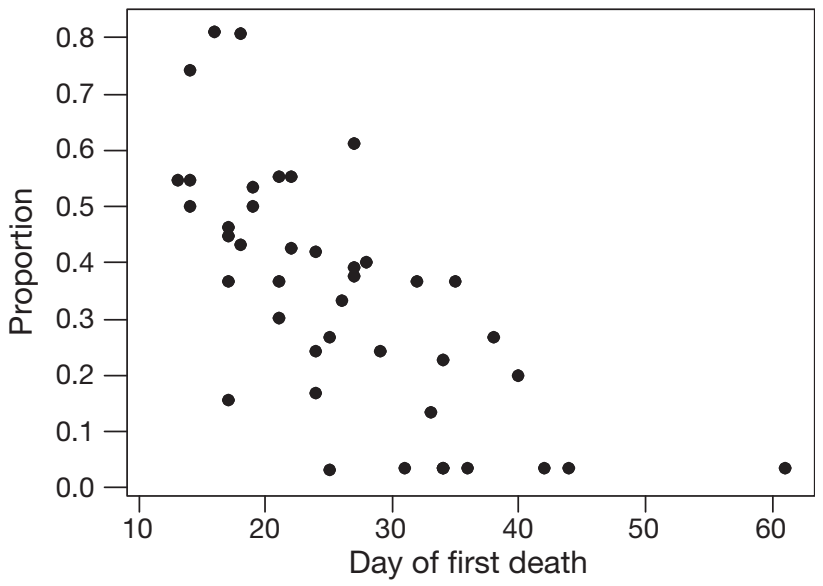

Fig. 2. Scophthalmus maximus. Scatterplot of proportion of mortalities against day of first death for tanks in which at least 1 death, due to viral haemorrhagic septicaemia virus, took place. A Spearman's rank correlation coefficient of -0.714 $(\mathrm{p}<0.001)$ was computed for the data 


\section{DISCUSSION}

Fish were challenged via a water-borne route, thus better reflecting natural VHSV infection, which is believed to occur by horizontal transmission of waterborne virus (Wolf 1988). Using this infection method, we have identified a relationship between the genotypic classification of VHSV isolates and their virulence in turbot. All isolates tested from Genotypes Ia (rainbow trout freshwater isolates) and II (Baltic marine isolates) resulted in low mortality in turbot $(\leq 5.7 \%)$, with no significant difference in mortality between isolates belonging to these groups. This supports previous preliminary observations that isolates from these genotypes cause low mortality in turbot following immersion infection (King et al. 2001a). The single North American isolate tested (Genotype IV) also resulted in low mortality, similar to that obtained with Genotype Ia and II isolates. All isolates representing Genotypes Ib (Baltic marine isolates) and III (North Sea, E. Atlantic isolates), however, resulted in significantly higher levels of cumulative mortality in turbot than isolates from Genotypes Ia and II. The highest levels of mortality were obtained with Genotype III isolates, though the difference between mortalities obtained with Genotype Ib was of borderline significance. This was due largely to the fact that one isolate in each of these groupings had a high mortality compared to the other isolates that inflated the variance associated with each data-set. Mortality obtained using Genotype Ib isolates in this and other studies ranged from 18.0 to $44.9 \%$ and 0.9 to $39.0 \%$ (Table 1). Furthermore, in this study, one Genotype Ib isolate (DK-1p12) resulted in higher mortality than a Genotype III isolate (MLA98/4PT1) (Table 3). Taken together, these data suggest that Genotype Ib isolates cause a range of mortality levels in turbot and that genotype cannot be used as a reliable predictor of mortality in this case. Interestingly, in all studies the lowest mortalities attained using Genotype $1 \mathrm{~b}$ isolates were using isolates derived from sprat (DK-1p86, 0.9\%, King et al. 2001a; DK-1p121, 18.0\%, this study). The number of isolates tested in this study was, however, not sufficient to determine a relationship between virulence in turbot and host species from which the original isolation was made.

Individual mortalities were virologically tested to specifically identify the cause of death as VHSV. This method was selected over potentially more sensitive methods (e.g. RT-PCR) since viable virus should be recoverable from all mortalities resulting from clinical VHSV. This is emphasised by the recovery of VHSV, from approximately $99.0 \%$ of mortalities in this trial. The cause of death in the remaining $1.0 \%$ of mortalities recorded in this trial could not be directly attrib- uted to VHSV. These fish, the distribution of which was not uniform over the different isolates, were excluded from the data analysis. Indeed, over half of these events occurred in only 2 of the 57 tanks used in this study. These mortalities may have been caused by environmental conditions in these tanks or by pathogens other than VHSV.

Although mortalities obtained in replicate treatments were generally consistent, some variation was noted. This may be due to variability in uptake and dissemination of virus in individual fish resulting in differing or prolonged secondary challenge of cohabiting fish. In addition, virus shed from infected fish could differ from the original tissue-culture-grown virus which could account for variability following secondary challenge.

Cumulative percent mortalities obtained for isolates which have been previously tested in our experimental facility have revealed some variation in the results obtained compared to this study (Table 1) (Snow \& Smail 1999, King et al. 2001a). Other workers have also reported mortality of $24.0 \%$ in juvenile turbot following water-borne infection with Isolate $07-71$ (Genotype Ia) (Castric \& de Kinkelin 1984). The same isolate was, however, responsible for mortality of $1.1 \%$ in this study. These findings serve to emphasise the variability inherent to fish challenge experiments and highlight a need to exercise caution in directly comparing the results of independent experiments. Such variability could be a result of a wide range of factors including differences in the challenge virus preparation, different husbandry conditions and the use of different life stages or genetic stocks of fish. The overall trend in relative mortalities obtained by studies comparing isolates from multiple genotypes was, however, consistent and supports the trends identified in this study.

A general trend was identified which indicated that the occurrence of first mortality was related to the cumulative level of mortality obtained with isolates. The earliest deaths were thus associated with Genotype Ib and III isolates. Earlier death could result from a more efficient replication of these viruses within the host, which may be related to the ability to evade or interfere with the host innate immune response. Mortality has previously been shown to be dose dependent in turbot and to also be prevented by elevated temperature (Castric \& de Kinkelin 1984). The production of interferon was proposed to explain the lack of susceptibility at such temperatures (Castric \& de Kinkelin 1984). Interestingly, a number of interferon responsive genes have recently been shown to be expressed in rainbow trout as a result of early infection with VHSV (O'Farrell et al. 2002). Different interaction with the host interferon system might thus account for the variation in relative virulence of VHSV isolates observed in this study. 
Although the mechanisms governing the virulence of VHSV remain unclear, it is evident from this study that virulence in turbot is related to genotypic classification. Indeed, virulence in turbot was related to the geographic distribution of isolates rather than the host species from which they were recovered. The genotypic classification of VHSV has been shown to be independent of the genomic region used for phylogenetic analysis (Einer-Jensen et al. 2004, Snow et al. 2004). This suggests that differences in the apparent virulence properties between genotypes are associated with their divergent evolution. Whether these virulence factors resulted from positive selection or were fixed within each genotype as a result of chance remains unclear. In the case of the latter scenario, the relative genetic stability of naturally occurring marine VHSV (Einer-Jensen et al. 2004) may contribute to the conservation of phenotypic properties observed within genotypes. Analysis of the relative virulence of further marine isolates of VHSV in turbot will no doubt further determine the extent to which genotype can be used to predict virulence properties in this species.

In summary, we have identified a correlation between the genotypic classification of VHSV isolates and levels of mortality obtained in turbot following waterborne horizontal infection. Such information is of significance in assessing the risk factors associated with the development of turbot mariculture in different geographic areas and resulting from anthropogenic activity. The demonstration that Genotype III isolates caused the highest mortalities highlights the risk to turbot culture conducted where these viruses are endemic. This is supported by the isolation of Genotype III isolates from 2 outbreaks of clinical VHS in turbot farmed in the British Isles (Ross et al. 1994, Snow et al. 2004). It remains to be seen whether the genotypic classification of isolates will prove a robust and useful marker of predicted virulence in turbot. The identification of such virulence trends is, however, of fundamental importance to understanding virulence determinants, which in the case of VHSV appear to be species specific.

Acknowledgements. The authors thank Ben Williamson and Rory Long for work in the aquarium and the virology group at FRS. Thanks also to the many individuals in the Aquaculture and Aquatic Animal Health Programme who helped with fish sampling.

\section{LITERATURE CITED}

Benmansour A, Basurco B, Monnier AF, Vende P, Winton JR, de Kinkelin P (1997) Sequence variation of the glycoprotein gene identifies three distinct lineages within field isolates of viral haemorrhagic septicaemia virus, a fish rhabdovirus. J Gen Virol 78:2837-2846
Brudeseth BE, Evensen O (2002) Occurrence of viral haemorrhagic septicaemia virus (VHSV) in wild marine fish species in the coastal regions of Norway. Dis Aquat Org 52:21-28

Brunson R, True K, Yancey J (1989) VHS virus isolated at Makah National Fish Hatchery. Am Fish Soc Newsl 17:3

Castric J, de Kinkelin P (1984) Experimental study of the susceptibility of two marine fish species, sea bass (Dicentrarchus labrax) and turbot (Scophthalmus maximus), viral haemorrhagic septicaemia. Aquaculture 41:203-212

Dixon PF, Feist S, Kehoe E, Parry L, Stone DM, Way K (1997) Isolation of viral haemorrhagic septicaemia virus from Atlantic herring Clupea harengus from the English Channel. Dis Aquat Org 30:81-89

Einer-Jensen K, Ahrens P, Forsberg R, Lorenzen N (2004) Evolution of the fish rhabdovirus viral haemorrhagic septicaemia virus. J Gen Virol 85:1167-1179

Hopper K (1989) The isolation of VHSV from chinook salmon at Gleenwood Springs, Orcas Island, Washington. Am Fish Soc Newsl 17:1

Jensen NJ, Bloch B, Larsen JL (1979) The ulcus syndrome in cod (Gadus morhua) III. A preliminary virological report. Nord Vet 31:436-442

King JA, Snow M, Skall HF, Raynard RS (2001a) Experimental susceptibility of Atlantic salmon Salmo salar and turbot Scophthalmus maximus to European freshwater and marine isolates of viral haemorrhagic septicaemia virus. Dis Aquat Org 47:25-31

King JA, Snow M, Smail DA, Raynard RS (2001b) Distribution of viral haemorrhagic septicaemia virus in wild fish species of the North Sea, north east Atlantic Ocean and Irish Sea. Dis Aquat Org 47:81-86

Meyers TH, Winton JR (1995) Viral hemorrhagic septicaemia in North America. Ann Rev Fish Dis 5:3-24

Meyers TR, Sullivan J, Emmenegger E, Follet J, Short S, Batts WN, Winton JR (1992) Identification of viral hemorrhagic septicemia virus isolated from Pacific cod Gadus macrocephalus in Prince William Sound, Alaska, USA. Dis Aquat Org 12:167-175

Meyers TR, Short S, Lipson K, Batts WN, Winton JR, Wilcock J, Brown E (1994) Association of viral hemorrhagic septicemia virus with epizootic hemorrhages of the skin in Pacific herring Clupea harengus pallasi from Prince William Sound and Kodiak Island, Alaska, USA. Dis Aquat Org 19:27-37

Meyers TR, Short S, Lipson K (1999) Isolation of the North American strain of viral hemorrhagic septicemia virus (VHSV) associated with epizootic mortality intwo new host species of Alaskan marine fish. Dis Aquat Org 38:81-86

Mortensen HF, Heur OE, Lorenzen N, Otte L, Olesen NJ (1999) Isolation of viral haemorrhagic septicaemia virus (VHSV) from wild marine fish species in the Baltic sea, Kattegat, Skagerrak and the North Sea. Virus Res 63:95-106

Nishizawa $T$, Iida $H$, Takano $R$, Isshiki $T$, Nakajima $K$, Muroga K (2002) Genetic relatedness among Japanese, American and European isolates of viral hemorrhagic septicemia virus (VHSV) based on partial G and P genes. Dis Aquat Org 48:143-148

O'Farrell C, Vaghefi N, Cantonnet M, Buteau B, Boudinot P, Benmansour A (2002) Survey of transcript expression in rainbow trout leukocytes reveals a major contribution of interferon-responsive genes in the early response to a rhabdovirus infection. J Virol 76:8040-8049

Ross K, McCarthy U, Huntly PJ, Wood P, Stuart D, Rough EI, Smail DA, Bruno DW (1994) An outbreak of viral haemor- 
rhagic septicaemia (VHS) in turbot (Scophthalmus maximus ) in Scotland. Bull Eur Assoc Fish Pathol 14:213

Schlotfeldt HJ, Ahne W, Jørgensen PEV, Glende W (1991) Occurrence of viral haemmorhagic septicaemia in turbot (Scophthalmus maximus) - a natural outbreak. Bull Eur Assoc Fish Pathol 11:105-107

Skall HF, Slierendrecht WJ, King JA, Olesen NJ (2004) Experimental infection of rainbow trout Oncorhynchus mykiss with viral haemorrhagic septicaemia virus isolates from European marine and farmed fishes. Dis Aquat Org 58:99-110

Smail DA (1995) Isolation and identification of viral haemorrhagic septicaemia (VHS) virus from north sea cod (Gadus morhua L.) ICES CM 1995/F:15 Mariculture Committee

Smail DA (2000) Isolation and identification of viral haemorrhagic septicaemia (VHS) viruses from cod Gadus morhua with the ulcus syndrome and from haddock Melanogrammus aeglefinus having skin haemorrhages in the North Sea. Dis Aquat Org 41:231-235

Snow M, Smail DA (1999) Experimental susceptibility of turbot Scophthalmus maximus to viral haemorrhagic septicaemia virus isoloted from cultivated turbot. Dis Aquat Org 38:163-168

Snow M, Cunningham CO, Melvin WT, Kurath G (1999) Analysis of the nucleoprotein identifies distinct lineages of viral haemorrhagic septicaemia virus within the European marine environment. Virus Res 63:35-44

Snow M, Bain N, Black J, Taupin V, Cunningham CO, King JA, Skall HF, Raynard RS (2004) Genetic population struc-

Editorial responsibility: Jo-Ann Leong,

Kaneohe, Hawaii, USA ture of marine viral haemrrhagic septicaemia virus (VHSV). Dis Aquat Org 61:11-21

Stone DM, Way K, Dixon PF (1997) Nucleotide sequence of the glycoprotein gene of viral haemorrhagic septicaemia (VHS) viruses from different geographical areas: a link between VHS in farmed fish species and viruses isolated from North Sea cod (Gadus morhua L.). J Gen Virol 78:1319-1326

Takano R, Nishizawa T, Arimoto M, Muroga K (2000) Isolation of viral hamorrhagic septicaemia virus (VHSV) from wild Japanese flounder, Paralichthys olivaceus. Bull Eur Assoc Fish Pathol 20:186-192

Thiery R, de Boisseson C, Jeffroy J, Castric J, de Kinkelin P, Benmansour A (2002) Phylogenetic analysis of viral haemorrhagic septicaemia virus (VHSV) isolates from France (1971-1999). Dis Aquat Org 52:29-37

Traxler GS, Kieser D (1994) Isolation of the North American strain of viral hemorrhagic septicemia virus (VHSV) from herring (Clupea harengus pallasi) in British Columbia. Fish Health Sec Am Fish SocNewsl 22:8

Traxler GS, Keiser D, Richard J (1999) Mass mortality of pilchard and herring associated with viral haemorrhagic septicaemia virus in British Columbia, Canada. Fish Health Sec Am Fish Soc Newsl 22:8

Wolf K (1988) Viral hemorrhagic septicemia. In: Fish viruses and fish viral diseases. Cornell University Press, Ithaca, NY, p 217-248

Wolf K, Quimby MC (1966) Lymphocystis virus: isolation and propagation in centrarchid fish cell lines. Science 151:1004-1005

Submitted: March 10, 2005; Accepted: July 8, 2005

Proofs received from author(s): October 26, 2005 